\title{
EDITORIAL
}

\section{ENFERMEIRAS (OS) E SUA PROFISSÃO}

No dia 22 de julho de 1981 fará cinqüenta anos que entrou em vigor a primeira regulamentação legal da profissão de enfermeiro no Brasil. Nessa data fora publicado o Decreto $n .^{\circ}$ 20.109. Esse Decreto seguiu-se a dois outros, todos estruturando a primeira escola do sistema Nightingale, em nosso País. Regulamenta a profissão de enfermeiro (a) diplomado (a).

Ora, havia no Brasil determinados centros que já formavam enfermeiros, tais como o Ministério do Exército (então da Guerra) e a Cruz Vermelha Brasileira; e, também, o próprio Ministério ao qual se subordinava a Escola Ana Neri, em outro Serviço do mesmo Departamento, mantinha escola qưe formava enfermeiros. Esta última referência é à então Escola de Enfermeiros Alfredo Pinto, hoje da UNI-RIO. O mencionado Decreto n. 20.109 , de 1931, bem como outro anterior, quando foram planejados e assinados, não se destinavam a vigorar subitamente em todos os centros acima referidos, que formavam enfermeiros. $E$ certo que as novas exigências (de duração do curso, qualificação em enfermagem para o diretor e alguns professores, exigência de Curso Normal ou instrução secundária bastante para o candidato à matrícula, entre outras) em tempo, iriam ocasionar melhoria no exercício do profissional.

Quanto a entrar em vigor, cada um daqueles outros centros, acima citados, teria que decidir, se desejava continuar como estava, ou mudar para a ordem nova. Neste último caso, o título do profissional egressado da escola seria enfermeiro diplomado.

Entretanto, houve uma boa surpresa para as enfermeiras líderes que planejaram o Decreto n. ${ }^{\circ}$ 20.109/31: no ano seguinte, um novo Decreto, desta vez o de n. ${ }^{\circ} 20.931$, de 11 de janeiro de 1932 - destinado a regular e fiscalizar o exercício da medicina, da odontologia, da medicina veterinária e das profissões de farmacêutico, parteira e enfermeira - só inclưư a denominação de enfermeiro. A denominação profissional no Brasil passa a ser uma só; não haveria mais a denominação de "enfermeiro(a) diplomado(a)". Retirou-se a adjetivação. Então, como resultado, rodos os centros de formação de enfermeiros teriam que ser atraídos, cada um no seu ritmo de mudança, para virem a adotar o sistema Nightingale. 
Tal fato, talvez forturito, foi de grande importância para se firmar a enfermagem brasileira, que hoje representa, sem dưvida, um dos traços de nossa cultura em ascensão.

Devemios thos orgulhat de nossa profissão. E certo que somas dos povos do Terceiro Mundo. Falta-nos, portanto, muita coisa ainda. Mas, no contexto em que deve ser feita uma apreciação geral, certos desempenhos da enfermagem não deixam de nos alegrar. Citemos o aspecto - justamente o destacado nosse editorial.

Em 1979, o Conseltho Internacional de Enfermeiros tinha 89 paises mem. bros. Pois bem. Estes e outros mais contam com legislação do exercício da profissão de enfermeiro. $E_{m} 1931$, apenas 27 países no mundo tinham leis do exercício dessa profissão. O Brasil estava entre eles. Fora o Decreto n. ${ }^{\circ}$ 20.109 que nos tinha classlificado nesse grupo, que era o adiantado quanto à legislação.

Cabe a esta altura uma reflexão. Tenhamos cada um de nós, enfermeiros, o propósito de eleviar para padröes mais altos rosso modo de desempenhar a enfermagem no Brasil. (H.G.D.) 